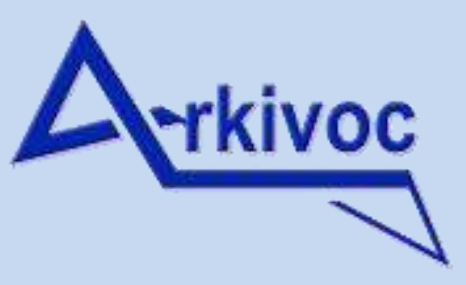

Free to Authors and Readers
A Platinum Open Access Journal for Organic Chemistry
Review

DOAJ Seal

Arkivoc 2021, part i, 48-54

\title{
Pyrethroid insecticides
}

\author{
Alain Krief \\ University of Namur, and International Organization for Chemical Sciences \\ in Development (IOCD), 61 Rue de Bruxelles, B-5000 Namur, Belgium \\ Email: alain.krief@unamur.be
}

\section{To the memory of Professor Alan Katritzky, for his dedication to chemistry and to chemists}

Received 08-07-2020

Accepted 11-16-2020

Published on line 02-11-2021

\section{Abstract}

Pyrethrins are a family of natural insecticides located in the flower head of Chrysanthemum cinerariifolium. Chemists have modified the original structures and extended their insecticidal properties to the benefit of mankind and under consideration of ecology and ethics in a transdisciplinary research endeavor that has covered almost a century. We expect that this review will allow teachers to produce material in their own language, in the format and at the level they judge most adequate for the message they want to transmit, and at the same time will allow students to access freely the same data and knowledge.

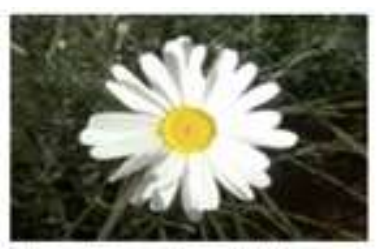

Chrysanthemum cineraeiaefolium flower containing pyrothrin I

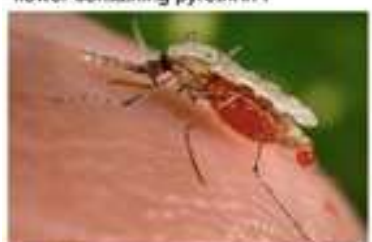

Anophele mosquilto transmitting malaria Him Gathany, Conters for Ososse Contro isenticesion number $\mathbf{s} 814$
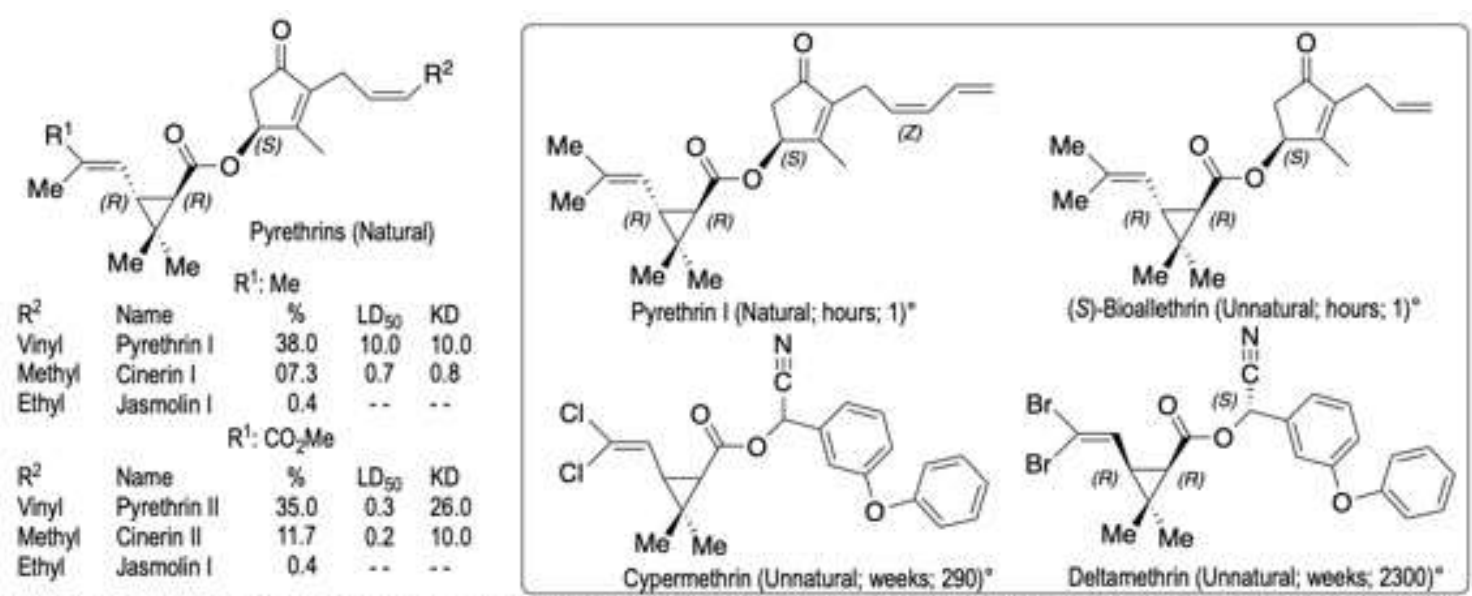

$\mathrm{LD}_{50}$ : Dose causing deah in $50 \%$ of the treated organism; $\mathrm{KD}$ : Relative knochdown factor, "Refers to : Origin; persistence in the environment; relative insecticidal potency

Keywords: Pyrethroids, pyrethrins, insecticides, rethrolones, chrysanthemic acid, cypermethrinic acids 


\section{Organization}

This review is organised into seven chapters that will be published separately in Arkivoc.

Chapter I. Structural and biochemical behavior of pyrethroids;

Chapter II. Synthesis of rethrolones;

Chapter III. Synthesis of 3-phenoxymandelonitrile, a building-block in permethrin synthesis;

Chapter IV. Reactivity of chrysanthemic and permethrinic acids;

Chapter V. Synthesis of the cyclopropane ring on the way to chrysanthemic and permethrinic acids;

Chapter VI. Synthesis of chrysanthemic and permethrinic acids by building the proper appendages around a prebuilt cyclopropane ring;

Chapter VII. Human versus computer-assisted synthesis of pyrethrins and pyrethroids.

To introduce the subject, a brief account of the impact of insects on human life and a general discussion of the ways in which man has fought back when challenged by them is presented.

\section{Introduction and General Discussion}

\subsection{Insects as pests}

Although insects are invaluable in their aptitude to fertilize plants by pollination and to produce, in the case of honey bees, a highly valuable food, a few of them interact with humans either competitively or in other ways. ${ }^{1}$ In fact, of 700000 insect species, a mere hundred can be regarded as pests. ${ }^{2}$ They:

(i) compete for food (Locusta migratoria the desert locust, Leptinotarsa decemlineata the colorado or potato beetle, Helicoverpa zea, the corn earworm or cotton bollworm, which is a noctuid moth), Cydia pomonella the codling moth), feeding on food crops;

(ii) destroy crops and trees threatening human economy [vine (Phylloxera), cotton (Spodoptera littoralis), tobacco (Helioverpa zea), olive trees (Philaenus spumarius, vector of the bacterium Xylella fastidiosa), elms (Scolytis spp. the elm bark beetles)];

(iii) act as vectors for possibly life-threatening diseases such as plague, leishmaniansis especially visceral leishmaniansis (fleas), typhus (lice), malaria, yellow fever, dengue and Zika fever (mosquitoes), lyme disease (ticks), and skin and allergic diseases (mites). ${ }^{2}$

As a consequence, men have fought insects from very early times, ${ }^{1,3}$ and crop protection can be estimated at the cost of $\$ 6$ billions/year. ${ }^{2}$

Fumigation with sulfur was first used $(1000 \mathrm{BC}$ ), followed by natural extract of plants (such as pyrethrins, in the Middle Ages, ${ }^{3,4}$ Figure 1), inorganic compounds [lead arsenate $\left(\mathrm{PbHAsO}_{4}\right)$, cryolite $\left(\mathrm{Na}_{3} \mathrm{AlF}_{6}\right)$ and borax $\left(\mathrm{Na}_{2} \mathrm{~B}_{4} \mathrm{O}_{7}\right)$ ], organic compounds (DDT, 1939) $)^{2,5,6}$ and bacterial, fungal and viral agents as well as DNA insecticides. $^{3}$

Insecticides should be adapted to the type of insect to fight (flying, crawling, swimming, moving in the soil), the conditions (indoor or outdoor use) and the ambient conditions (temperature, humidity, sunlight) and therefore the choice is context dependent. Anyhow, they should be:

(i) highly toxic to the target category of insects $\left(L D_{50}\right)$, but should not harm other species such as fish, birds and mammals;

(ii) possess a very powerful knock-down effect $(K D)^{7}$ that should almost instantaneously paralyze the insects preventing them for example biting other species or to infest fruit with their eggs before dying; 
(iii) stable enough to protect for just the required time, being eco-friendly with the proper remanence;

(iv) possess limited soil persistence, except for soil insecticides;

(v) unaffected by resistance of insects over the years;

(vi) Readily available at low cost

None of the different classes of insecticides that have been marketed fulfill those requirements.

Pyrethrins, ${ }^{8,9}$ (Figure 1), the active principles of the ground flower-head of some chrysanthemum plants ${ }^{2,3}$ (such as Chrysanthemum cinerariifolium a plant that originates from Dalmatia, now part of Croatia), occupy a special place.

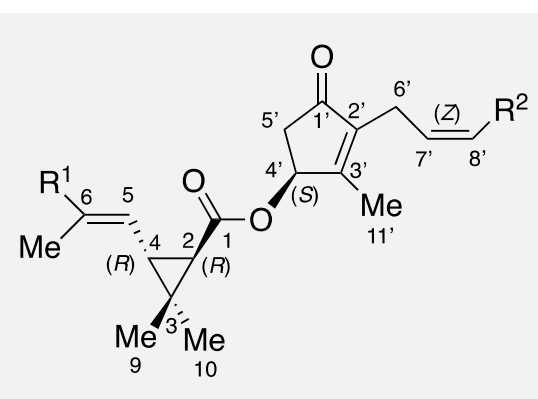

\begin{tabular}{|c|c|c|c|c|c|c|}
\hline $\mathrm{N}^{\circ}$ & $\mathrm{R}^{1}$ & $\mathrm{R}^{2}$ & Name & $\%^{a}$ & $\mathrm{LD}_{50} \mathrm{~b}^{\mathrm{b}}$ & $K D^{c}$ \\
\hline $1 a$ & $\mathrm{CH}_{3}$ & $\mathrm{CH}=\mathrm{CH}_{2}$ & Pyrethrin I & 38 & 10 & 10 \\
\hline $1 b$ & $\mathrm{CO}_{2} \mathrm{CH}_{3}$ & $\mathrm{CH}=\mathrm{CH}_{2}$ & Pyrethrin II & 35 & 03 & 26 \\
\hline $1 c$ & Me & $\mathrm{CH}_{3}$ & Cinerin I & 07.3 & 07 & 08 \\
\hline $1 d$ & $\mathrm{CO}_{2} \mathrm{CH}_{3}$ & $\mathrm{CH}_{3}$ & Cinerin II & 11.7 & 02 & 10 \\
\hline $1 e$ & Me & $\mathrm{CH}_{2} \mathrm{CH}_{3}$ & Jasmolin I & 04.0 & & \\
\hline $1 f$ & $\mathrm{CO}_{2} \mathrm{CH}_{3}$ & $\mathrm{CH}_{2} \mathrm{CH}_{3}$ & Jasmolin II & 04.0 & & \\
\hline
\end{tabular}

Figure 1. Natural pyrethrins: their structures, ${ }^{a}$ their relative amount in Chrysanthemum cinerariaefolium. ${ }^{\mathrm{b}}$ Their activity $\left(L_{50}\right.$ refers to the lethal dose $\left(L_{50}\right)$, the dose that causes death in $50 \%$ of the treated organisms generally expressed as $\mathrm{mg}$ of chemical per $\mathrm{kg}$ of body weight. ${ }^{\mathrm{c}}$ relative knockdown factor.

\subsection{Development of the pyrethrins and other insecticides}

The insecticidal properties of various kinds of chrysanthemum plants have been noticed since the Middle Ages in various parts of the world (Dalmatia, Persia, China) and the ground plants have been used as "Persian powder", "Persian dust" or "Insect powder" since that time to protect the people living in those areas. ${ }^{2-4,11}$

Increasing demand in Europe (1820), in the US (1880) and in Japan (1885) has led to intensive cultivation in Japan, Kenya, Rwanda, Tanzania, China and Papua New Guinea, owing to the suitable climate in those countries, of Chrysanthemum cinerariifolium whose content in active principle is the highest $(1.5 \%$ in the ground flower head). Japanese pyrethrum production reached a peak of 13000 tons/year in 1938 (70\% of the world's production at that time) and declined to only 1000 tons in 1965 at the time that synthetic analogs, the pyrethroid family, entered the market. ${ }^{13,14}$

Pyrethrum has been used quite early (1890) to produce mosquito-burning sticks active for $1 \mathrm{~h}$, then coils with prolonged burning time $(7 \mathrm{~h}) .{ }^{11}$ Extraction of the flowers with organic solvents proved to be more efficient with the more benign supercritical carbon dioxide, ${ }^{15}$ producing up to $50 \%$ of oily pyrethrin extracts devoid of the natural resin present in the powder that possesses allergenic properties, that is used in spray as household insecticide (USA, 1919) or as oil-based preparations (Japan, 1924). ${ }^{16}$

Pyrethrum was used to fight a typhus epidemic in Naples in December 1943 but was supplanted by DDT (Figure 2), a more persistent synthetic insecticide, whose properties were discovered by P. Müller, a scientist at the Geigy company who won the Nobel Medicine Prize in $1948^{6,17}$ on the strength of this discovery.

DDT was used to eradicate malaria in Europe $(1975)^{6,10,18}$ and would have achieved a similar result in other parts of the world had it not been banished worldwide due to its strong persistence in the environment and its accumulation in the fat of almost all living organisms. ${ }^{18}$ 


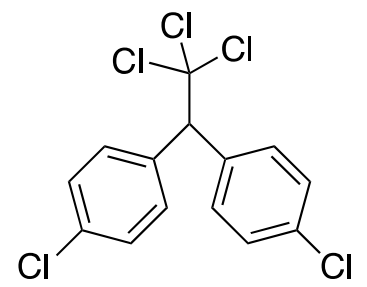

Figure 2. Dichlorodiphenyl trichloroethane (DDT).

New insecticides, less persistent than DDT but more stable than pyrethrins, were needed and expected to be produced by structural modifications of the latter. Those however must retain the advantages that pyrethrins already possess over DDT to kill insects at much lower dose (Table 1), to be almost harmless to mammals, and to possess a powerful knock down effect. ${ }^{6,18}$

Table 1. Lethal doses of different series of insecticides and related selectivity factors

\begin{tabular}{lccc}
\hline & $\mathrm{LD}_{50}$ in insects $\mathrm{mg} \cdot \mathrm{kg}^{-1}$ & $\mathrm{LD}_{50}$ in rats, $\mathrm{mg} \mathrm{kg}^{-1}$ & Selectivity factor \\
\hline Pyrethroids & 0.45 & 2000 & 4500 \\
Carbamates & 2.8 & 45 & 16 \\
Organophosphates & 2.0 & 67 & 33 \\
Organochlorines & 2.6 & 230 & 91 \\
\hline
\end{tabular}

Pioneer work (1909) by chemists ${ }^{4,11}$ led to the isolation by Fujitani ${ }^{19}$ of some of the pyrethrins (1a-f) (Figure 1) as the active principle of Chrysanthemumum cinerariifolium. The presence of compounds possessing at least a $\mathrm{C}=\mathrm{C}$ double bond, a cyclopropane ring and an ester group was suggested by the isolation by Yamamoto of trans-caronic acid (4) (Figure 3) on hydrolysis of this active principle followed by ozone oxidation (1923). ${ }^{20,21}$ Staudinger and Ruzicka ${ }^{22}$ proposed the structures of pyrethrin I and II (1a, 1b, Figure 1; 1924, with minor errors in the location of the unsaturations). Laforge ${ }^{23}$ discovered the cinerins (1c, 1d, Figure $\left.1 ; 1945\right)$ and Gordins ${ }^{24}$ the jasmolins (1e, 1f, Figure 1; 1966).

Finally, the absolute configuration of the carboxyl moieties part of the chrysanthemic acid (2a) (Figure 2, 1954) were elucidated by Crombie, ${ }^{25}$ that of the related chrysanthemum acid (2b) (Figure 3, 1955) by Inoue, ${ }^{26}$ and that of the natural rethrolones (3a-c) by Katsuda ${ }^{27}\left((S)\right.$; Figure 3, 1958). ${ }^{14}$

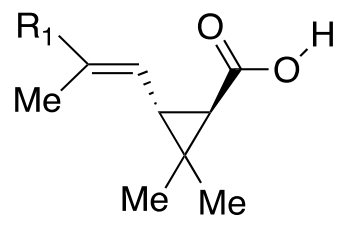

2a; $R_{1}=$ Me: Chrysanthemic acid

2b; $\mathrm{R}_{1}=\mathrm{CO}_{2} \mathrm{Me}$ : Pyrethric acid

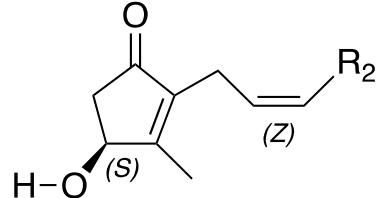

3a; $\mathrm{R}_{2}=\mathrm{CH}=\mathrm{CH}_{2}$ : Pyrethrolone

3b; $\mathrm{R}_{2}=\mathrm{CH}_{3}$ : Cinerolone

3c; $\mathrm{R}_{2}=\mathrm{CH}_{2} \mathrm{CH}_{3}$ : Jasmololone

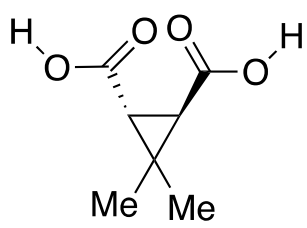

4; trans-Caronic acid

Figure 3. Names and structures of constituents of pyrethrins and of related compounds.

Staudinger and Ruzicka [Nobel prizes in 1953 and 1939 respectively] ${ }^{28}$ reported in 1924 the first synthesis of ethyl chrysanthemate (1 $\left.\mathbf{a}_{E t}\right)$ from 2,6-dimethylhexadiene (5) and ethyl diazoacetate (6a) in the presence of 
copper bronze but its yield was very low (8\%) due to the poor quality of (5) and to the heterogeneity of the medium. They were unable however to synthesize the pyrethrolone (3a) since their structural assignment proved later to be incorrect and therefore they never achieved the synthesis of pyrethrin I (1a). ${ }^{4,8}$

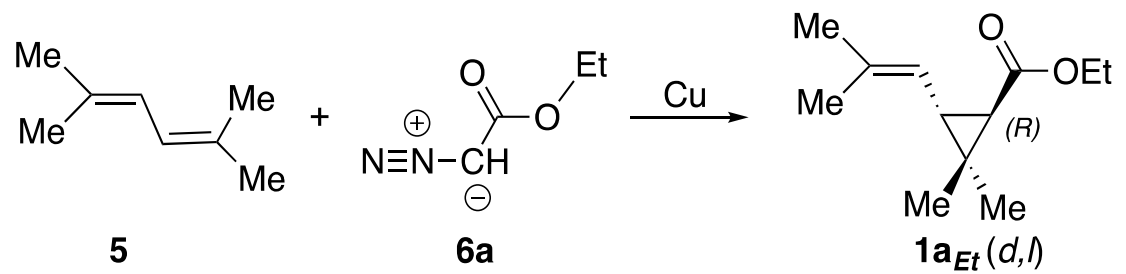

Scheme 1. First synthesis of ethyl chrysanthemate by Staudinger in 1924.

Since then chemists in academia, research centers and chemical companies have succeeded to design, synthesize and market unnatural semi-synthetic or synthetic analogues the pyrethroids that possess exceptional properties adapted to contextual enviremental (against flying, crawling and soil insects) and economic needs. ${ }^{14}$

A more detailed account of the biosynthesis of natural pyrethrins in the plants and of the structure and properties of some of the most important commercially available unnatural analogues the pyrethroides, will be presented in Chapter 1, which follows this Introductory section.

\section{References}

1. Meyers, C. L. “Exodus” Cambridge University Press, 2005.

https://doi.org/10.1017/CBO9780511806377

ISBN 0521002915052180781697805218078149780521002912. (Exodus 10.1-20)

2. Elliott, M. L'Actualité Chimique 1990, 157, 57-70.

3. Oberemok, V.V.; Laikova, K.V.; Gninenko, Y. I.; Zaitsev, A. S.; Nyadar, P. M.; Adeyemi, T. A. Journal of Plant Protection Research 2015, 55, 221-225.

https://doi.org/10.1515/jppr-2015-0033

4. Roth, K.; Vaupel, E. I "Pyrethrum: History of a bio-insecticide, Part 1 "Chrysanthemum flower as an insecticide" In ChemViews Mag. 2018

https://doi.org/10.1002/chemv.201800089

5. Roth, K.; Vaupel, E. "Pyrethrum: History of a bio-insecticide, Part 3 "Comparing the insecticidal activity of DDT and pyrethrins" In ChemViews Mag. 2018.

https://doi.org/10.1002/chemv.201800113

6. Davies, T. G. E.; Field, L. M.; Usherwood, P. N. R.; Williamson, M. S. IUBMB Life 2007, 59, $151-162$. https://doi.org/10.1080/15216540701352042

7. Matsuo, N. Pestic. Sci. 1998, 52, 21-28.

https://doi.org/10.1002/(SICI)1096-9063(199801)52:1<21::AID-PS690>3.0.CO;2-D

8. Roth, K.; Vaupel, E. "Pyrethrum: History of a bio-insecticide, Part 2 "The chemical structures of pyrethrins and insecticide use between the world wars" In ChemViews Mag. 2018.

https://doi.org/10.1002/chemv.201800105

9. Roth, K.; Vaupel, E. "Pyrethrum: History of a bio-insecticide, Part 4 "The comeback of pyrethrin research" In ChemViews Mag. 2018. 
https://doi.org/10.1002/chemv.201800122

10. Roth, K.; Vaupel, E. "Pyrethrum: History of a bio-insecticide, Part 5 "The fall of DDT and the rise of pyrethrin derivatives" In ChemViews Mag. 2019.

https://doi.org/10.1002/chemv.201900009

11. Matsuo, N.; Mori, T. "Pyrethroids from chrysanthemum to modern industrial insecticide" In Top. Curr. Chem. Eds, Springer, 2012, 314.

https://doi.org/10.1007/978-3-642-27346-9

12. Elliott, M.; Janes, N. F.; Potter. C. Ann. Rev. Entomol. 1978, 23, 443-469.

https://doi.org/10.1146/annurev.en.23.010178.002303

13. Katsuda, Y. "Pyrethroids from chrysanthemum to modern industrial insecticide" "Progress and future of pyrethroids" In Top. Curr. Chem. Matsuo, N.; Mori, T. Eds, Springer, 2012, 314, 1-30.

https://doi.org/10.1007/978-3-642-27346-9

14. Matsuo, N. Proc. Jpn. Acad., Ser. B 2019, 95, 378-400.

https://doi.org/10.2183/pjab.95.027

15. Gallo, M.; Formato, A.; Ianniello, D.; Andolfi, A.; Conte, E.; Ciaravolo, M.; Varchetta, V.; Naviglio, D. J. Supercritical Fluids 2017, 119, 104-112 and references cited.

https://doi.org/10.1016/j.supflu.2016.09.012

16. Ujihara, K.; Mori, T.; Matsuo, N. "Pyrethroids from chrysanthemum to modern industrial insecticide" "Recent advances of Pyrethroids for Household use" In Top. Curr. Chem., Matsuo, N.; Mori, T. Eds, Springer, 2012, 314, 31-48.

https://doi.org/10.1007/128 2011253

17. Müller, P. "Paul Müller Biographical", The Nobel Prize in Physiology or Medicine 1948. https://www.nobelprize.org/prizes/medicine/1948/muller/biographical/

18. Zubrin, R. The truth about DDT and Silent Spring, 2012 https://www.thenewatlantis.com/publications/the-truth-about-ddt-and-silent-spring

19. Fujitani, J. Arc. Exp. Path Pharmak. 1909, 61, 47-75. https://doi.org/10.1007/BF01841115

20. Yamamoto, R. J. Chem. Soc. Japan 1923, 44, 311.

21. Yamamoto, R. Inst. Phys. Chem. Res. Tokyo 1923, 3, 193.

22. Staudinger, H.; Ruzička, L. Helv. Chim. Acta 1924, 7, 177-458. https://doi.org/10.1002/hlca.19240070150

23. LaForge, F. B.; Barthel, W. F. J. Org. Chem. 1945, 10, 114-120. https://doi.org/10.1021/jo01178a004

24. Godin, P. J.; Sleeman, R. J.; Snarey, M.; Thain, E. M. J. Chem. Soc. C, 1966, 332-334. https://doi.org/10.1039/J39660000332

25. Crombie, L.; Harper, S. H. J. Chem. Soc. 1954, 470. https://doi.org/10.1039/JR9540000470

26. Inouye, Y.; Takeshita, Y.; Ohno, M. Bull. Agric. Chem. Soc. Jpn 1955, 19, 193-199. https://doi.org/10.1080/03758397.1955.10857288

27. Katsuda, Y.; Chikamoto, T.; Inouye, Y. Bull. Agric. Chem. Soc. Jpn 1958, 22, 427-428. https://doi.org/10.1080/03758397.1958.10857510

28. Staudinger, H.; Muntwyler, O.; Ruzicka, L.; Seibt, S. Helv. Chim. Acta 1924, 7, 390-406. https://doi.org/10.1002/hlca.19240070147 


\section{Author's Biography}

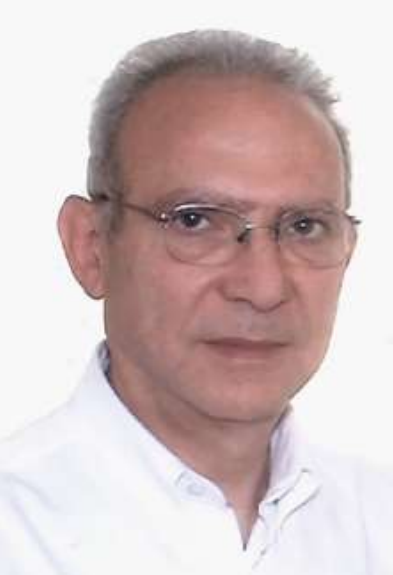

Alain Krief studied chemistry at the University "Pierre et Marie Curie" in Paris where he completed his Ph.D. on ynamine chemistry in 1970 under the supervision of the late Professor Jacqueline Ficini. He then moved to Harvard University in $\mathbf{1 9 7 0}$ for a postdoctoral stay in the laboratory of Professor Elias J. Corey where he worked, on sterol biosynthesis. In 1972, he joined the "Facultés Universitaires Notre-Dame de la Paix", now University of Namur, Namur, Belgium, where he created a new lab and was appointed until his retirement in 2008. Professor Krief has focused his research on several different topics all of them related in one way or another to organic synthesis - organoselenium chemistry, synthesis of small bioactive compounds including several syntheses of chrysanthemic acid, selenomethionine and in collaboration with Dr. Paul Janssen to an effective anti-HIV medicine sold presently by Janssen Pharma, mechanism of the biosynthesis of steroids, use of antibodies in synthesis, management of chemical knowledge. In 1980, although actively collaborating on pyrethroids with the Roussel Uclaf Company (Romainville, France), he spent eight months with ICl Plant Protection Division (Bracknell, UK) as an invited scientist, working on herbicides.

He has been the Executive Director (2018-2020) of the International Organization for Chemical Sciences in Development (IOCD) under the directorship of Prof. Jean-Marie Lehn (Strasbourg) and involved in research in organic chemistry at the HEJ Research Institute (Pakistan), in inorganic chemistry at the University of Namur (Belgium) and at the iThemba labs (South Africa). With a group of three other scientists [Profs H. Hopf (Germany), S.M. Matlin (UK) and G. Mehta (India)] he participates in the frame of IOCD (C4S group) to writing essays to promote chemistry and chemists. 